\title{
PENGARUH POLYETHYLENE GLYCOL (PEG) TERHADAP KADAR KUERSETIN KULTUR KALUS Chrysanthemum morifolium Ramat PADA KONDISI PENCAHAYAAN BERBEDA
}

\section{EFFECT OF POLYETHYLENE GLYCOL (PEG) ON QUERCETIN CONTENTS IN Chrysanthemum morifolium Ramat CALLUS CULTURE IN DIFFERENT LIGHTING CONDITIONS}

\author{
Tia Setiawati*, Syifa Fauzia Zazuli, Annisa, Mohamad Nurzaman, Budi Irawan \\ Program Studi Biologi Fakultas MIPA Universitas Padjadjaran, Jl. Raya Bandung-Sumedang Km.21 Jatinangor \\ *Corresponding author: tia@unpad.ac.id
}

Naskah Diterima: 13 Desember 2019; Direvisi: 19 Februari 2020; Disetujui: 17 Maret 2020

\begin{abstract}
Abstrak
Krisan (Chrysanthemum morifolium Ramat) mengandung senyawa kuersetin dengan efek farmakologi yang sangat luas. Penambahan polyethilene glycol (PEG) dapat dimanfaatkan untuk meningkatkan produksi metabolit sekunder secara in vitro. Penelitian ini bertujuan untuk mengetahui pengaruh PEG terhadap pertumbuhan kalus krisan dan kadar kuersetin 3-O-rhamnosida pada pencahayaan yang berbeda. Penelitian menggunakan Rancangan Acak Lengkap (RAL). Eksplan kalus berumur 45 hari setelah tanam (HST) disubkultur pada media MS + 4 ppm 2,4-D dengan penambahan PEG dalam lima taraf konsentrasi yaitu 0, 10, 20, 30, dan 40 ppm. Kultur diinkubasi pada kondisi gelap dan terang. Parameter yang diamati adalah warna, tekstur, ukuran, berat basah, dan berat kering kalus serta kadar kuersetin 3-O-rhamnosida. Data kuantitatif dianalisis menggunakan Analisis Varians dan Uji Jarak Berganda Duncan ( $\alpha$ 5\%), sedangkan data kualitatif dianalisis secara deskriptif. Hasil penelitian menunjukkan bahwa kalus pada kondisi terang berwarna cokelat dan cokelat kehijauan, sedangkan pada kondisi gelap berwarna putih kecokelatan. Perlakuan 10 ppm PEG menghasilkan berat basah dan berat kering kalus tertinggi baik pada kondisi terang maupun gelap berturut-turut $1,97 \mathrm{~g}$ dan 2,92 g; 0,94 g dan 1,09 g. Kadar kuersetin 3-Orhamnosida tertinggi pada kondisi gelap dan terang terdapat pada perlakuan 10 ppm PEG berturutturut $1,72 \mu \mathrm{g} / \mathrm{g}$ berat kering (BK) dan 2,59 $\mu \mathrm{g} / \mathrm{g} \mathrm{BK}$.
\end{abstract}

Kata kunci: Cahaya; Kalus; Krisan; Kuersetin; PEG

\begin{abstract}
Chrysanthemum morifolium Ramat. contains quercetin with extensive pharmacological effects. The addition of PEG can be used to increase the production of secondary metabolites using in vitro method. This study aimed to determine the effect of PEG on the growth of Chrysanthemum callus and quercetin 3-O-rhamnoside content in different lighting conditions. The experimental design used was a Completely Randomized Design. After 45 days, callus were subcultured on MS medium + 4 ppm 2,4-D which PEG was added in five concentration levels $(0,10,20,30$, and $40 \mathrm{ppm})$. The culture was incubated in dark and light conditions. Parameters observed were color, texture, size, wet weight and dry weight of callus, also quercetin 3-Orhamnoside levels. Quantitative data were analyzed using Analysis of Variance and Duncan's Multiple Distance $(\alpha 5 \%)$. Qualitative data were analyzed descriptively. The results showed that in light condition, the callus has brown and greenish-brown color, whereas in the dark, it has brownish-white color. The ten ppm PEG treatment produced the highest fresh weight and dry weight in both light and dark conditions of $1.97 \mathrm{~g}$ and $2.92 \mathrm{~g}, 0.94 \mathrm{~g}$ and $1.09 \mathrm{~g}$, respectively. The highest quercetin 3-O-rhamnoside contents in dark and light conditions were founded in $10 \mathrm{ppm}$ PEG treatment of $1.72 \mu \mathrm{g} / \mathrm{g}$ dry weight $(\mathrm{DW})$ and $2.59 \mu \mathrm{g} / \mathrm{g} \mathrm{DW}$.
\end{abstract}

Keywords: Callus; Chrysanthemum; Light; PEG, Quercetin

Permalink/DOI: http://dx.doi.org/10.15408/kauniyah.v13i1.13688 


\section{PENDAHULUAN}

Chrysanthemum morifolium atau krisan lebih dikenal sebagai tanaman hias namun sebenarnya dapat dimanfaatkan sebagai tanaman obat. Pada tanaman ini, terdeteksi kadar flavonoid diantaranya luteolin-7glucoside, quercetin-3- glucoside, quercitrin, myricetin, luteolin dan apigenin (Sun, Hua, Ye, Zheng, \& Liang, 2010). Quercitrin merupakan turunan kuersetin yang ditemukan dalam kadar paling tinggi mencapai 21,8\% mg/g (Sun et al., 2010). Penelitian Xie, Yuan, Yang, Wang, dan Wu (2009) menunjukkan bahwa metabolit sekunder yang terkandung dalam krisan memiliki fungsi untuk menghilangkan kelemahan otot pada jantung dan mengurangi efek ritme yang terlalu keras pada detak jantung. Kuersetin memiliki manfaat sebagai antioksidan, antikanker, antifungal, antiviral, antiinflamasi, antibakteri, dan antidiabetes (Smith, Oertle, Warren, \& Prato, 2016) dan memberikan efek perlindungan terhadap ginjal dari kerusakan yang diakibatkan efek samping senyawa nefrotoksik seperti antibiotik golongan aminoglikosida, anti radang golongan nonsteroid anti-imflamation drug (NSAID), dan obat kemoterapi (Gomes et al., 2014).

Melihat besarnya potensi $C$. morifolium sebagai bahan baku obat, maka perlu dilakukan upaya untuk menghasilkan metabolit sekunder dengan cara yang lebih efektif, salah satunya melalui kultur jaringan. Metabolit sekunder diperoleh secara konvensional dengan cara mengekstraksi langsung dari organ tanaman. Namun, terkendala karena diperlukan budi daya tanaman dalam skala besar, selain itu proses ekstraksi, isolasi, dan pemurniannya memerlukan biaya relatif mahal (Chattopadhyay, Sunita, Ashok, \& Virendra, 2002). Metode kultur jaringan memiliki kelebihan yaitu dapat dilakukan produksi senyawa alami secara kontinu, dapat diandalkan (Vanisree et al., 2004), dan meningkatkan produktivitas berlipat (Chattopadhyay et al., 2002). Salah satu jenis kultur yang terbukti mampu mengakumulasi metabolit sekunder adalah kultur kalus (Rao, Usha, \& Arjun, 2015; Ali \& Asi, 2012; Janarthanam, Gopalakrishnan, \& Sekar, 2010).

Produksi metabolit sekunder secara in vitro dilaporkan masih relatif rendah, oleh karena itu diperlukan metode yang dapat meningkatkan kadar metabolit sekunder, salah satunya dengan penambahan elisitor. Elisitor adalah senyawa yang mampu menginduksi pembentukan senyawa tertentu sebagai respon pertahanan tanaman akibat cekaman lingkungan (Angelova, Georgiev, \& Roos, 2006). PEG merupakan senyawa dengan berat molekul tinggi, berperan sebagai agen osmotik yang dapat menimbulkan stres berupa cekaman kekeringan pada tanaman. Penambahan PEG mengakibatkan menurunnya potensial air pada media kultur, sehingga pertumbuhan eksplan terhambat dan meningkatkan kadar metabolit sekunder (Kacem, Delporte, Muhovski, Djekoun, \& Wattilon, 2017). Shehab, Ahmed, dan El-Beltagi (2010) melaporkan adanya peningkatan kadar senyawa fenol pada kultur kalus padi dalam kondisi cekaman akibat penambahan PEG. Pada penelitian lain disebutkan bahwa produksi metabolit sekunder steviol glikosida pada kultur kalus Stevia rebaudiana menunjukkan peningkatan setelah penambahan PEG 5\% (Gupta, Sharma, \& Saxena, 2015).

Akumulasi metabolit sekunder pada kultur jaringan tanaman dapat juga dipengaruhi oleh faktor lingkungan seperti cahaya. Cahaya memengaruhi pengaturan produksi bahan metabolit sekunder seperti antosianin, flavonol, dan karotenoid (Ariany, Sahiri, \& Abdul, 2013). Kebutuhan cahaya untuk menghasilkan metabolit sekunder yang maksimal berbeda tergantung jenis tanaman. Kondisi gelap pada kultur Lithospermum erythrorhizon menyebabkan produksi shikonin menjadi terhambat (Yazaki, Matsuoka, Ujihara, \& Sato, 1999), sedangkan pada Uncarina rhynchophyll, lingkungan gelap meningkatkan produksi alkaloid (Kawazoe, Kobayashi, Mizukami, \& Ohashi, 1989). Penelitian lain pada Thymus vulgaris yang diberi perlakuan cahaya dapat meningkatkan kadar monoterpenoid (Sharafzadeh, 2012). Penelitian ini bertujuan untuk mengetahui pengaruh pemberian PEG dalam berbagai konsentrasi terhadap pertumbuhan dan kadar kuersetin kultur kalus krisan pada kondisi pencahayaan yang berbeda yaitu kondisi terang dan gelap. 


\section{MATERIAL DAN METODE Alat dan Bahan}

Alat yang digunakan dalam penelitian ini diantaranya peralatan kultur, laminar air flow cabinet, High Performance Liquid Chromatography (HPLC), centrifuge, autoklaf, hot plate magnetic stirrer, oven, neraca analitik, shaker.

Bahan-bahan yang digunakan dalam penelitian ini yaitu planlet $C$. morifolium Ramat kultivar Yulimar yang diperoleh dari Dinas Pertanian Tanaman Pangan Holtikultura dan Aneka Tanaman Pasir Banteng SumedangJawa Barat, medium Murashige-Skoog (MS) (Phytotech), metanol p.a (Merck KGaA), PEG 6.000 (Merck), standar kuersetin 3-Orhamnosida (SIGMA), spirtus, sukrosa, zat pengatur tumbuh 2,4-D, agar bubuk, alkohol $70 \%$, dan akuades.

\section{Rancangan Percobaan}

Penelitian menggunakan Rancangan Acak Lengkap (RAL). Eksplan berupa kalus berumur 45 hari disubkultur pada media perlakuan, yaitu media MS + 4 ppm 2,4-D yang telah ditambahkan PEG 6.000 dalam lima taraf konsentrasi yaitu 0 ppm, 10 ppm, 20 ppm, $30 \mathrm{ppm}$, dan $40 \mathrm{ppm}$. Kultur diinkubasi pada kondisi gelap dan terang. Masing-masing perlakuan dilakukan pengulangan sebanyak 5 kali.

\section{Prosedur Penelitian \\ Pembuatan Media Perlakuan}

Media perlakuan yang digunakan adalah media MS dengan penambahan sukrosa 30 $\mathrm{g} / \mathrm{L}$, agar $9 \mathrm{~g} / \mathrm{L}$, ZPT 2,4-D 4 ppm dan PEG sebagai perlakuan dalam berbagai konsentrasi yaitu 0 ppm, 10 ppm, $20 \mathrm{mg} / \mathrm{L}, 30$ ppm, dan 40 ppm. Kemasaman $(\mathrm{pH})$ media diatur menggunakan $\mathrm{pH}$ meter hingga mencapai 5,8 dengan menambahkan $\mathrm{NaOH}$ atau $\mathrm{HCl} 1 \mathrm{~N}$. Media dipanaskan hingga mendidih kemudian dituangkan ke dalam botol-botol kultur sebanyak sekitar 10-15 mL. Media selanjutnya disterilkan menggunakan autoklaf selama 60 menit dengan suhu $121{ }^{\circ} \mathrm{C}$ dan tekanan 1,5 $\mathrm{kg} / \mathrm{cm}^{2}$.

\section{Induksi Kalus dan Penanaman Eksplan pada Media Perlakuan}

Kalus diinduksi dari eksplan daun planlet krisan yang dipotong dengan ukuran kurang lebih $1 \mathrm{~cm}^{2}$ dan ditanam pada media $\mathrm{MS}+4$ ppm 2,4-D (Purwaningsih, Febri, \& Kusdianti, 2016). Botol kultur berisi eksplan disimpan dalam ruang penyimpanan dengan suhu 26-28 ${ }^{\circ} \mathrm{C}$ dengan intensitas cahaya 2.500 lux selama 45 hari. Kultur kalus yang berumur 45 HST ditanam sebanyak $1 \mathrm{~g}$ ke dalam medium perlakuan yaitu medium MS + 4 ppm 2,4-D yang telah ditambahkan PEG dengan konsentrasi yang telah ditentukan sebagai perlakuan. Kalus diinkubasi pada dua kondisi pencahayaan yang berbeda yaitu gelap dan terang (2.500 lux) selama 45 hari.

\section{Pengamatan dan Analisis Data}

Pengamatan dilakukan pada 45 hari setelah tanam (HST) terhadap parameter warna dan tekstur kalus, ukuran kalus, berat basah dan berat kering kalus serta kadar kuersetin 3$O$-rhamnosida yang dianalisis menggunakan High Performance Liquid Chromatography (HPLC). Ukuran kalus dilakukan menggunakan skala clay models (Humaira \& Amien, 2019).

Data hasil pengamatan dianalisis secara statistik menggunakan ANOVA .Jika terdapat perbedaan nyata, maka dilakukan Uji Jarak Berganda Duncan pada taraf 5\%. Untuk data warna dan tekstur kalus dianalisis secara deskriptif.

\section{Penentuan Kadar Kuersetin Ekstraksi, Preparasi Sampel dan Larutan Standar}

Kalus dikeringkan menggunakan oven, kemudian dihaluskan dan sebanyak $0,25 \mathrm{~g}$ diekstraksi dengan $10 \mathrm{~mL}$ larutan (metanolasam asetat-akuades $100: 2: 100$ ) selama satu jam menggunakan shaker pada suhu ruangan. Sebanyak $2 \mathrm{~mL}$ ekstrak disentrifugasi selama 10 menit pada $2.000 \mathrm{rpm}$. Larutan kemudian disaring menggunakan membran filter selulosa dengan ukuran $0,22 \mu \mathrm{m}$. Filtrat digunakan untuk analisis HPLC (Moghaddasian, Eradatmand, \& Alaghemand, 2012). Larutan stok standar kuersetin dilarutkan dalam metanol pada konsentrasi 200 ppm, 150 ppm, dan $100 \mathrm{ppm}$. Larutan standar disaring dengan membran filter berukuran 0,22 $\mu \mathrm{m}$. Selanjutnya larutan standar dapat disuntikkan pada sistem HPLC secara langsung (Moghaddasian et al., 2012). 


\section{Analisis HPLC}

Analisis kromatografi dilakukan menggunakan kolom C18 (4,6 mm x $250 \mathrm{~mm})$ sebagai fase diam dan campuran metanol, asetonitril, akuades (10:10:75) yang mengandung 5\% asam asetat sebagai fase gerak A dan metanol p.a sebagai fase gerak B. Detektor UV dengan panjang gelombang 368 $\mathrm{nm}$, laju alir $1,0 \mathrm{~mL} / \mathrm{menit}$, dan volume injeksi $10 \mu \mathrm{m}$. Puncak kromatografi dianalisis dengan membandingkan waktu retensi dan spektrum UV dengan standar referensi (Moghaddasian et al., 2012) yang dimodifikasi.Perhitungan kadar kuersetin dilakukan menggunakan persamaan sebagai berikut: $\mathrm{Cx}=\mathrm{Ax} / \mathrm{Ap} \mathrm{x} \mathrm{Cp}$. Keterangan: $\mathrm{A}=$ Luas Puncak; $\mathrm{C}=$ Konsentrasi; $\mathrm{X}=$ Sampel; $\mathrm{P}=$ Pembanding (Seenivasan, Gummadi, Panda, \& Theodore, 2015).

\section{HASIL}

Pengaruh Konsentrasi PEG terhadap Kualitas Kalus (Warna, Tekstur, Berat dan Ukuran) Krisan (C. morifolium) pada Kondisi Pencahayaan yang Berbeda

Pengamatan tekstur dan warna kalus dilakukan secara visual, sedangkan ukuran kalus dilakukan menggunakan skala clay models. Pada penelitian ini, kalus krisan yang ditumbuhkan pada media MS + 4 ppm 2,4-D dengan lima taraf konsentrasi PEG memberikan respon yang beragam, baik pada warna, tekstur maupun ukuran kalus (Tabel 1 dan Gambar 1).

Tabel 1 dan Gambar 1 menunjukkan bahwa pada seluruh perlakuan, kalus yang diinkubasi pada kondisi terang memiliki warna cokelat pekat, sedangkan pada kondisi terang berwarna putih kecokelatan namun memiliki tekstur seragam yaitu remah. Secara umum kalus menunjukkan ukuran lebih besar pada kondisi gelap namun pada konsentrasi PEG tertinggi (40 ppm) berukuran lebih kecil. Ukuran kalus cenderung mengalami penurunan sejalan dengan meningkatnya konsentrasi PEG. Secara umum, pada seluruh medium perlakuan terbentuk kalus berakar baik pada kondisi gelap maupun terang. Kondisi berakar dapat disebabkan oleh penambahan ZPT auksin 2,4-D. Diketahui bahwa salah satu peran auksin adalah mendorong proses morfogenesis kalus membentuk akar.

Parameter berat basah dan berat kering dianalisis menggunakan ANOVA yang menunjukkan bahwa perlakuan konsentrasi PEG berpengaruh nyata terhadap kedua parameter tersebut baik pada kondisi gelap maupun terang. Untuk mengetahui perbedaan antar perlakuan dilakukan uji Jarak Berganda Duncan yang hasilnya dapat dilihat pada Tabel 2.

Tabel 2 menunjukkan bahwa rata-rata berat basah dan berat kering kalus tertinggi baik yang diinkubasi pada kondisi terang dan maupun gelap terdapat pada perlakuan $10 \mathrm{ppm}$ PEG yang berbeda nyata dengan perlakuan lainnya. Rata-rata berat basah tertinggi pada kondisi terang dan gelap berturut-turut sebesar $1,97 \mathrm{~g}$ dan $2,92 \mathrm{~g}$, sedangkan rata-rata berat kering tertinggi berturut-turut sebesar $0,94 \mathrm{~g}$ dan $1,09 \mathrm{~g}$.

Tabel 1. Tekstur, warna, dan ukuran kalus krisan (C. morifolium) pada berbagai konsentrasi PEG dan kondisi pencahayaan yang berbeda

\begin{tabular}{cccccccc}
\hline $\begin{array}{c}\text { Konsentrasi } \\
\text { PEG }\end{array}$ & \multicolumn{2}{c}{ Tekstur kalus } & \multicolumn{2}{c}{ Warna kalus } & \multicolumn{2}{c}{$\begin{array}{c}\text { Ukuran kalus } \\
\text { (clays model) }\end{array}$} & Keterangan \\
\cline { 2 - 6 } & Terang & Gelap & Terang & Gelap & Terang & Gelap & \\
\hline $0 \mathrm{ppm}$ & Remah & Remah & $\begin{array}{c}\text { Cokelat tua } \\
\text { kehijauan }\end{array}$ & Putih kecokelatan & 18 & 20 & Kalus + akar \\
$10 \mathrm{ppm}$ & Remah & Remah & $\begin{array}{c}\text { Cokelat tua } \\
\text { Cokelat tua } \\
20 \mathrm{ppm}\end{array}$ & Putih kecokelatan & 19 & 20 & Kalus + akar \\
$30 \mathrm{ppm}$ & Remah kecokelatan & 17 & 18 & Kalus + akar \\
$40 \mathrm{ppm}$ & Remah & Remah & $\begin{array}{c}\text { Rokelat tua } \\
\text { kehijauan } \\
\text { Cokelat tua } \\
\text { kehijauan }\end{array}$ & Putih kecokelatan & 16 & 18 & Kalus + akar \\
\hline
\end{tabular}





10 ppm PEG (terang)

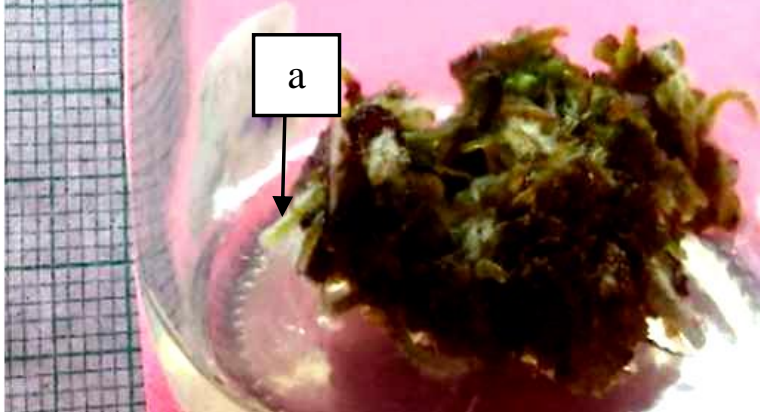

20 ppm PEG (terang)

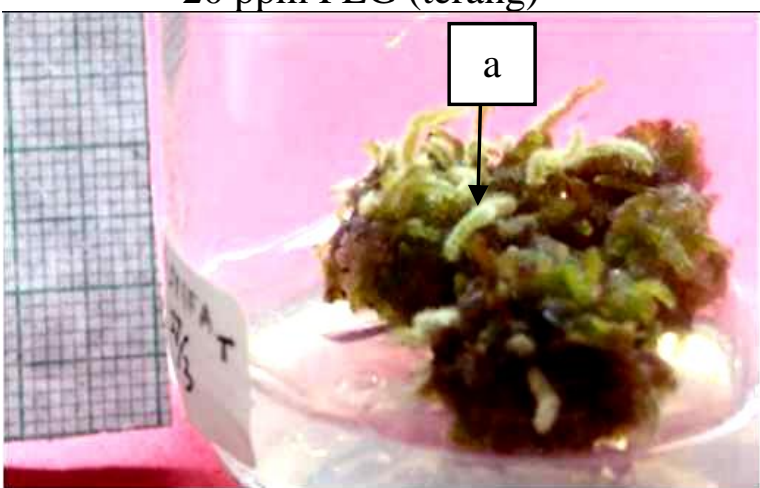

30 ppm PEG (terang)

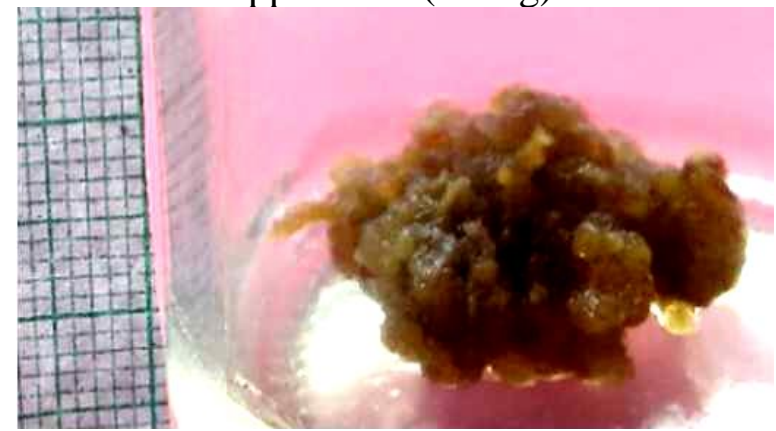

40 ppm PEG (terang)

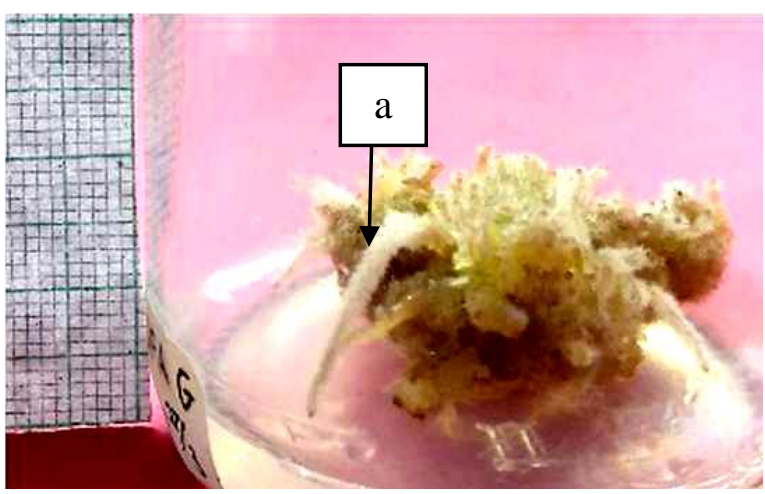

0 ppm PEG (gelap)

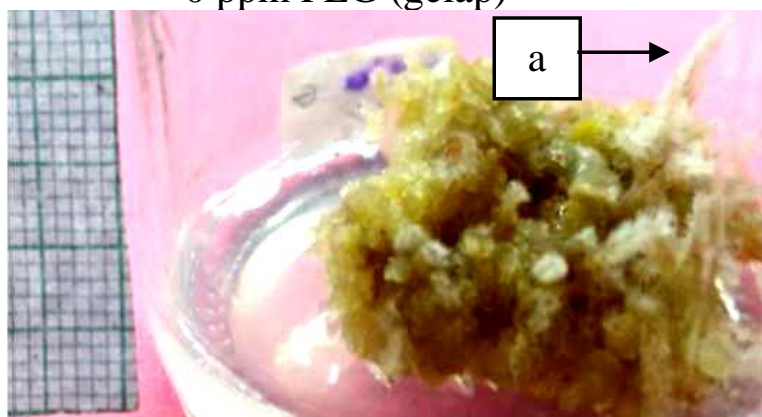

10 ppm PEG (gelap)

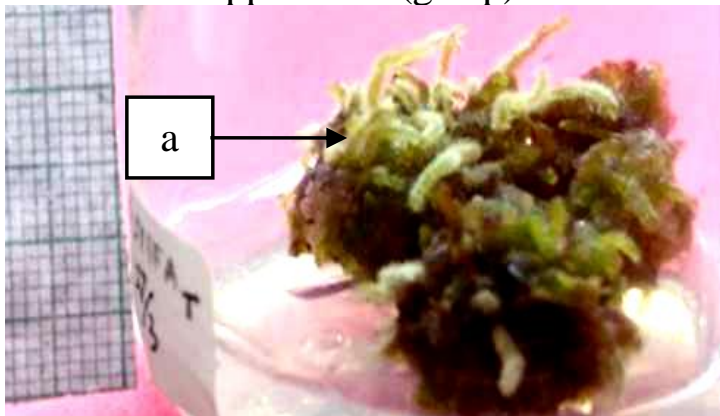

20 ppm PEG (gelap)

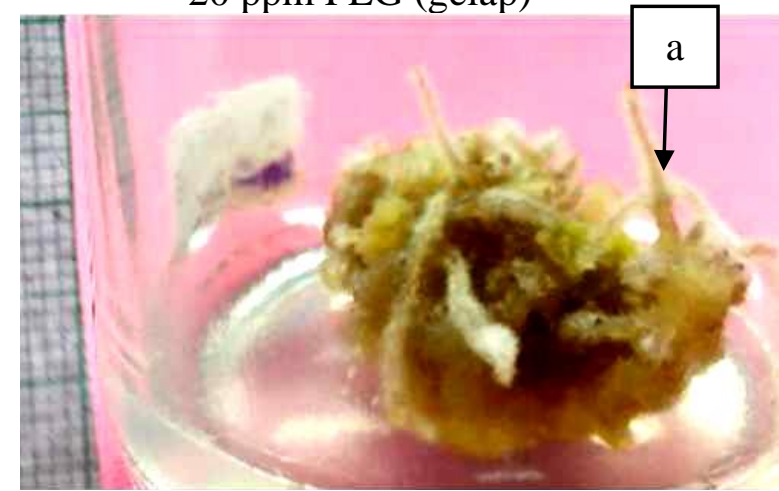

30 ppm PEG (gelap)

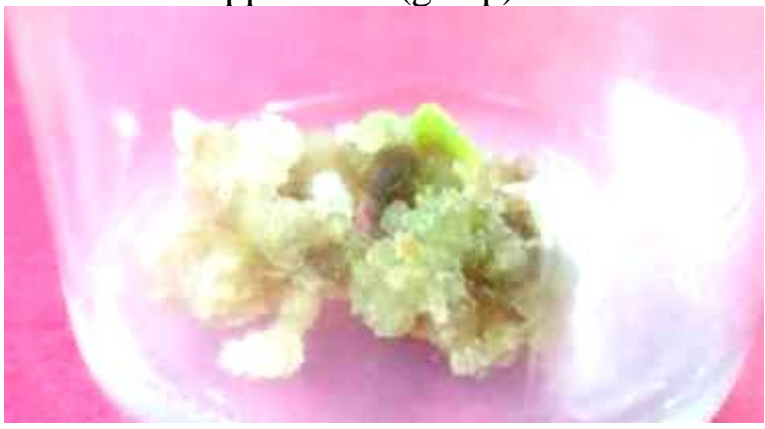

40 ppm PEG (gelap)

Gambar 1. Struktur kalus krisan (C. morifolium)pada berbagai konsentrasi PEG. (a) akar 
Tabel 2. Rata-rata berat basah (g) dan berat kering (g) kalus krisan (C. morifolium) pada berbagai konsentrasi PEG dalam kondisi pencahayaan yang berbeda

\begin{tabular}{ccccc}
\hline Perlakuan PEG & \multicolumn{2}{c}{ Berat basah $(\mathrm{g})$} & \multicolumn{2}{c}{ Berat kering $(\mathrm{g})$} \\
& Terang & Gelap & Terang & Gelap \\
\hline $0 \mathrm{ppm}$ & $1,78 \mathrm{~b}$ & $2,76 \mathrm{~b}$ & $0,63 \mathrm{c}$ & $0,97 \mathrm{~b}$ \\
$10 \mathrm{ppm}$ & $1,97 \mathrm{a}$ & $2,92 \mathrm{a}$ & $0,94 \mathrm{a}$ & $1,09 \mathrm{a}$ \\
$20 \mathrm{ppm}$ & $1,75 \mathrm{~b}$ & $2,86 \mathrm{~b}$ & $0,80 \mathrm{~b}$ & $1,01 \mathrm{~b}$ \\
$30 \mathrm{ppm}$ & $1,64 \mathrm{~b}$ & $2,74 \mathrm{~b}$ & $0,71 \mathrm{~b}$ & $0,97 \mathrm{~b}$ \\
$40 \mathrm{ppm}$ & $1,27 \mathrm{c}$ & $2,65 \mathrm{~b}$ & $0,67 \mathrm{c}$ & $0,74 \mathrm{c}$ \\
\hline
\end{tabular}

Keterangan: Nilai rata-rata yang diikuti huruf yang sama pada kolom yang sama menunjukkan tidak berbeda nyata $(\mathrm{P}<0,05)$

\section{Kadar Kuersetin 3-O-rhamnosida}

Hasil ANOVA menunjukkan bahwa PEG berpengaruh nyata terhadap kadar kuersetin 3-O-rhamnosida dan hasil Uji Jarak Berganda Duncan untuk melihat perbedaan antar perlakuan dapat dilihat pada Tabel 3.

Tabel 3 menunjukkan bahwa penambahan PEG pada konsentrasi $10 \mathrm{ppm}$ dan $20 \mathrm{ppm}$ mampu meningkatkan secara signifikan kadar kuersetin 3-O-rhamnosida kultur kalus krisan pada kondisi terang dan gelap. Perlakuan 10 ppm PEG menghasilkan rata-rata kadar kuersetin 3-O-rhamnosida tertinggi baik pada kondisi terang maupun gelap, berturut- turut yaitu $2,59 \mu \mathrm{g} / \mathrm{g}$ berat kering (BK) dan $1,72 \mu \mathrm{g} / \mathrm{g}$ BK yang berbeda nyata dengan kontrol dan perlakuan PEG lainnya kecuali perlakuan 20 ppm PEG.

Tabel 3. Rata-rata kadar kuersetin 3-O-rhamnosida kultur kalus krisan ( $C$. morifolium) pada berbagai konsentrasi PEG dan kondisi pencahayaan berbeda

\begin{tabular}{ccc}
\hline Perlakuan PEG & \multicolumn{2}{c}{$\begin{array}{c}\text { Kadar kuersetin3-O-rhamnosida } \\
(\mu \mathrm{g} / \mathrm{g} \text { berat kering })\end{array}$} \\
& Terang & Gelap \\
\hline $0 \mathrm{ppm}$ & $0,84 \mathrm{~b}$ & $1,23 \mathrm{~b}$ \\
$10 \mathrm{ppm}$ & $2,53 \mathrm{a}$ & $1,72 \mathrm{a}$ \\
$20 \mathrm{ppm}$ & $1,87 \mathrm{a}$ & $1,64 \mathrm{a}$ \\
$30 \mathrm{ppm}$ & $1,31 \mathrm{~b}$ & $1,06 \mathrm{~b}$ \\
$40 \mathrm{ppm}$ & $1,11 \mathrm{~b}$ & $0,95 \mathrm{~b}$ \\
\hline
\end{tabular}

Keterangan: Nilai rata-rata yang diikuti huruf yang sama pada kolom yang sama menunjukkan tidak berbeda nyata $(\mathrm{P}<0,05)$

\section{PEMBAHASAN}

Pengaruh Konsentrasi PEG terhadap Kualitas Kalus (Warna, Tekstur, Berat dan Ukuran) Krisan ( $C$. morifolium) pada Kondisi Pencahayaan yang Berbeda

Kalus krisan yang terbentuk dengan perlakuan beberapa konsentrasi PEG dan kondisi pencahayaan berbeda menunjukkan perbedaan warna yaitu putih kecokelatan, cokelat tua, serta cokelat tua kehijauan. Warna kalus menunjukkan perbedaan yang signifikan pada perlakuan pencahayaan yang berbeda. Kalus yang diinkubasi pada kondisi terang memiliki warna cokelat dan cokelat kehijauan, sedangkan pada kondisi gelap memiliki warna putih kecokelatan. Hasil ini menunjukkan bahwa cahaya memengaruhi warna kalus. Menurut Hendaryono dan Wijayani (1994) kondisi perubahan warna pada kalus dapat disebabkan adanya pigmentasi dan pengaruh cahaya. Kalus yang berwarna kecokelatan disebabkan oleh kadar fenol yang tinggi, sedangkan warna kehijauan pada kalus disebabkan adanya kandungan klorofil dalam jaringan. Hal ini sesuai dengan penelitian Tavakkol, Angoshtari, dan Kalantari (2011), kalus Sawi (Brassica napus L). yang ditanam pada intensitas cahaya tinggi memiliki warna kecokelatan dan memiliki banyak kloroplas sehingga terdapat warna hijau pada kalus.

Pada kondisi gelap, kalus yang terbentuk berwarna putih kecokelatan, hal ini disebabkan tidak terbentuk atau rendahnya jumlah kloroplas yang terkandung pada sel kalus. Hasil yang sama pada penelitian Behbahani, Mehrnaz, dan Mohamad (2011) menunjukkan 
kalus Butun (Barringtonia racemosa) yang ditanam pada kondisi gelap memiliki warna putih. Kalus yang diinkubasi pada kondisi gelap dengan konsentrasi PEG 0 ppm memiliki warna dominan putih, sedangkan pada perlakuan PEG 10-40 ppm warna kalus didominasi oleh warna kecokelatan (Gambar 1). Perubahan warna menjadi kecokelatan tersebut disebabkan oleh metabolisme senyawa fenol. Menurut Tabiyeh, Bernard, dan Shacker (2006) pencokelatan jaringan disebabkan oleh peningkatan produksi senyawa fenolik dan oksidasi selanjutnya oleh aktivitas enzim oksidase dan polimerisasinya. Penelitian Rao dan Jabeen (2013) menunjukkan bahwa semakin tinggi penambahan PEG pada media menyebabkan warna kalus tebu (Saccharum officinarum L.) semakin cokelat.

Perubahan warna kalus dapat juga disebabkan oleh ZPT yang ditambahkan pada media tumbuh. Penelitian ini menggunakan media MS dengan penambahan ZPT 4 ppm 2,4-D. Beberapa bagian kalus yang terbentuk dalam penelitian ini terdapat warna kehijauan yang dapat pula disebabkan oleh penambahan 2,4-D yang dapat memicu pembentukan klorofil pada kalus. Bagian yang berwarna putih pada kalus yang terbentuk dapat disebabkan oleh hilangnya polarisasi, dan apabila pada awalnya eksplan berwarna hijau sedangkan kalus yang terbentuk berwarna putih atau putih kecokelatan, berarti ada proses dekomposisi klorofil (Santoso \& Nursandi 2001).

Pada Tabel 1 terlihat bahwa kalus yang terbentuk pada semua perlakuan PEG (0-40 ppm) dengan penambahan 2,4-D baik yang diinkubasi pada kondisi terang maupun gelap memiliki tekstur remah. Menurut Manuhara (2014), kalus remah merupakan kalus yang tersusun atas sel-sel yang panjang berbentuk tubular, struktur sel-selnya renggang, tidak teratur, dan mudah rapuh. Pada penelitian ini kalus remah yang dihasilkan cenderung kadar airnya rendah. Hasil yang sama pada kalus remah Mucuna pruriens L. yang diinduksi 2,4$\mathrm{D}$, selain memiliki susunan sel yang renggang juga memiliki kadar air yang minim (Ariani, Anggraito, \& Rahayu, 2016). Minimnya kadar air sel pada kalus remah di penelitian ini tampaknya dapat disebabkan pula penambahan PEG yang menginduksi kekeringan pada media kultur. Penambahan PEG menyebabkan potensial air di dalam sel lebih tinggi daripada potensial air di medium, air akan bergerak dari sel menuju lingkungan (medium) yang mengakibatkan kadar air dalam sel menjadi rendah.

Penambahan PEG pada setiap konsentrasi tidak berpengaruh besar terhadap ukuran kalus, namun terdapat kecenderungan bahwa semakin tinggi konsentrasi PEG, ukuran kalus semakin mengecil. Pada perlakuan kontrol dan 10 ppm PEG menghasilkan ukuran kalus terbesar dengan ukuran 20 skala clay models. Ukuran kalus terkecil terdapat pada perlakuan 30 dan 40 ppm PEG dengan ukuran 16 skala clay models. Penurunan ukuran kalus tersebut dapat disebabkan oleh respon kalus terhadap stres lingkungan akibat penambahan PEG. Nadir, Syahrir, dan Syamsia (2018) menunjukkan adanya penghambatan pertumbuhan kalus Pennisetum purpureum akibat stres yang disebabkan penambahan 20 ppm 2,4-D dan 40 ppm PEG pada media MS. Pertumbuhan erat kaitannya dengan pertambahan ukuran, sehingga dengan terjadinya hambatan pertumbuhan kalus akibat pemberian PEG dapat menyebabkan penurunan ukuran kalus.

Berdasarkan hasil pengamatan, kondisi pencahayaan yang berbeda tidak memengaruhi tekstur kalus yang terbentuk. Kalus yang diinkubasi pada kondisi gelap dan terang memiliki tekstur yang sama yaitu remah. Hasil serupa diperoleh pada penelitian Moitreyee, Shrivastava, dan Singh (2013) yang menunjukkan bahwa kultur kalus Aquilaria malaccensis Lam. dengan penambahan ZPT 2,4-D pada media kultur menghasilkan kalus bertekstur remah, baik pada kondisi terang maupun gelap. Demikian pula dengan pengaruh pencahayaan terhadap ukuran kalus, menunjukkan tidak terlalu signifikan. Hal ini ditunjukkan dengan perbedaan ukuran kalus yang tidak begitu besar pada perlakuan gelap dan terang. Ukuran kalus terbesar terdapat pada perlakuan tanpa cahaya, yaitu 20 menurut skala clay models. Hasil yang sama ditunjukkan pada penelitian Kintzios et al. (2002) penanaman kalus Lavandula vera dengan perlakuan intensitas cahaya yang berbeda tidak memengaruhi ukuran kalus secara signifikan. 
Berdasarkan Tabel 2, rata-rata berat basah dan berat kering kalus menurun sejalan dengan meningkatnya konsentrasi PEG. Hal ini menunjukkan bahwa semakin tinggi konsentrasi PEG yang ditambahkan menyebabkan semakin besar efek hambatan pertumbuhan kalus. Rahayu, Guhardja, Ilyas, dan Sudarsono (2005) menyatakan bahwa PEG dapat menurunkan potensial osmotik melalui aktivitas matriks sub-unit etilena oksida yang mampu mengikat molekul air dengan ikatan hidrogen, dengan demikian ketersediaan air dalam media yang diperlukan jaringan menjadi berkurang. Peningkatan konsentrasi PEG mengakibatkan terhambatnya proses penyerapan air dan nutrisi yang disebabkan oleh penurunan potensial air pada media (tekanan turgor rendah), sehingga menurunkan pembelahan sel dan laju pemanjangan sel (Guo, Hao, Gong, Zhong, \& Gu, 2013; Jaleel et al., 2009) yang dapat berakibat pada penurunan berat kalus. Pada penelitian Gupta, Bains, dan Thind (2014) penanaman kalus pada media dengan penambahan PEG dapat mengurangi berat basah kalus tanaman Triticum aestivum $\mathrm{L}$.

\section{Kadar Kuersetin 3-O-rhamnosida}

Pada Tabel 3 tampak bahwa pemberian PEG mampu meningkatkan kadar kuersetin kultur kalus krisan. Serupa dengan penelitian Al-Oubaidi dan Al-Sowaidi (2015) yang menunjukkan bahwa penambahan PEG 6.000 pada kultur kalus Olea europaea L. terbukti meningkatkan kadar metabolit sekunder golongan fenol. Shreedhara (2013) menyatakan bahwa penambahan PEG dapat menyebabkan stres lingkungan pada kultur kalus Millingtonia hortensis sehingga dapat meningkatkan produksi metabolit sekunder hispidulin. Stres merupakan salah satu faktor yang memengaruhi produksi metabolit sekunder pada tumbuhan. Pada penelitian ini PEG digunakan untuk menciptakan kondisi stres osmotik pada kultur kalus krisan untuk memengaruhi kadar metabolit sekunder yang terkandung di dalamnya. Tumbuhan memiliki mekanisme adaptasi pada lingkungan dengan stres osmotik yang diinduksi dengan PEG. Peningkatan stres osmotik akibat penambahan PEG ini dapat menstimulasi produksi metabolit sekunder seperti fenol, terpenoid, dan alkaloid
(Selmar, 2008). Azhar, Hussain, Ashraf, dan Abbasi (2011) menyebutkan bahwa kadar metabolit sekunder golongan fenol pada Trachyspermum ammi L. meningkat secara signifikan akibat penambahan PEG. Stres osmotik pada kultur cabai (Capsicum chinensis) dapat meningkatkan produksi capsaicin (Kehie, Kumaria, \& Tandon, 2014) dan steviol glikosida pada kultur Stevia (Stevia rebaudiana) (Gupta et al., 2015).

Berdasarkan Tabel 3 diketahui bahwa terjadi peningkatan kadar kuersetin pada penambahan 10 ppm PEG. Hal ini dapat disebabkan sel-sel kalus mengalami tahap resistensi atau masa adaptasi terhadap faktor cekaman PEG yang diberikan. Pada tahap adaptasi , sel akan berusaha mempertahankan diri dengan cara mensintesis metabolit sekunder (dalam hal ini kuersetin). Penambahan PEG melebihi 10 ppm menyebabkan penurunan kadar kuersetin pada kultur kalus krisan baik pada kondisi terang maupun gelap. Penurunan kadar kuersetin terjadi seiring dengan naiknya konsentrasi PEG. Hasil ini menunjukkan bahwa efektivitas elisitor dipengaruhi konsentrasi elisitor, sebagaimana diungkapkan Vasconsuelo dan Boland (2007) yang menyatakan bahwa elisitasi dipengaruhi oleh spesifikasi elisitor, jenis, konsentrasi, dan waktu aplikasi elisitor. Konsentrasi elisitor merupakan salah satu faktor yang menentukan kadar metabolit sekunder pada kultur jaringan yang dielisitasi. Membran plasma memiliki reseptor untuk elisitor dengan jumlah tertentu, sehingga untuk meningkatkan kadar metabolit sekunder diperlukan konsentrasi elisitor yang optimum.

Tabel 3 menunjukkan juga bahwa ratarata kadar kuersetin 3-O-rhamnosida lebih tinggi pada kalus yang diinkubasi pada kondisi terang dibandingkan kondisi gelap. Hal ini menunjukkan bahwa cahaya memengaruhi produksi metabolit sekunder. Cahaya dapat menginduksi produksi nitrogen monoksida dan enzim nitric oxide synthase (NOS), sehingga memengaruhi aktivitas dari enzim phenylalanin ammonia lyase (PAL) yang berpengaruh pada sintesis flavonoid, seperti flavonoid pada kultur kalus Ginko biloba (Hao, Du, Zhao, Shi, \& Wang, 2009). Ramani dan Jayabaskaran (2008) melaporkan bahwa terdapat peningkatan catharanthine dan 
vindoline pada kultur Catharanthus roseus pada perlakuan cahaya. Penelitian lainnya yang membuktikan bahwa cahaya meningkatkan produksi metabolit sekunder seperti gingerol and zingiberene pada kultur kalus Zingiber officinale (Anasori \& Asghari, 2008) dan alkaloid pada kalus Hyoscyamus albus (Sauerwein, Wink, \& Shimomura, 1992). Namun, pada beberapa tanaman lebih efektif memproduksi metabolit sekundernya pada kondisi gelap, hal ini dapat disebabkan oleh sifat metabolit sekunder yang berbeda. Terdapat metabolit sekunder yang memiliki sensitivitas yang tinggi terhadap cahaya sehingga menyebabkan metabolit sekunder tesebut terdekomposisi. Menurut penelitian Kusbiantoro dan Purwaningrum (2018) metabolit sekunder kurkumin akan mengalami dekomposisi jika terkena cahaya, menjadi beberapa produk degradasinya yaitu asam ferulat, aldehid ferulat, dehidroksinaftalen, vinilquaikol, vanillin, dan asam vanilat.

\section{SIMPULAN DAN SARAN}

Pemberian berbagai konsentrasi PEG berpengaruh terhadap pertumbuhan dan kadar kuersetin 3-O-rhamnosida kultur kalus krisan (C. morifolium) secara in vitro yang diinkubasi dengan pencahayaan yang berbeda. Pada kondisi terang, kalus memiliki warna cokelat dan cokelat kehijauan, sedangkan pada kondisi gelap memiliki warna putih kecokelatan. Perlakuan 10 ppm PEG menghasilkan berat basah dan berat kering kalus tertinggi baik pada kondisi terang dan maupun gelap berturut-turut sebesar 1,97 g dan 2,92 g, 0,94 g dan 1,09 g. Demikian pula, kadar kuersetin 3$O$-rhamnosida tertinggi baik pada kondisi gelap maupun terang terdapat pada perlakuan $10 \mathrm{ppm}$ PEG berturut-turut sebesar $1,72 \mu \mathrm{g} / \mathrm{g}$ berat kering (BK) dan 2,59 $\mu \mathrm{g} / \mathrm{g} \mathrm{BK}$.

Diperlukan penelitian lebih lanjut dengan menggunakan elisitor yang berbeda selain PEG untuk mengetahui jenis elisitor terbaik yang dapat meningkatkan kadar kuersetin pada kalus krisan atau pun menggunakan jenis kultur lain selain kultur kalus.

\section{UCAPAN TERIMA KASIH}

Ucapan terimakasih disampaikan kepada Rektor Universitas Padjadjaran sehingga penelitian ini dapat terselenggara melalui dana Hibah Internal Unpad (HIU), Skema Riset
Fundamental Unpad (RFU) tahun anggaran 2018 dengan Kontrak No. 2403/UN6.D/KS/2018.

\section{REFERENSI}

Ali, H. T. S., \& Asi, M. R. (2012). Appraisal of an important flavonoid, quercetin, in callus cultures of Citrullus colocynthis. International Journal of Agriculture Biology, 14(4), 528-532.

Al-Oubaidi, H. K. M., \& Al-Sowaidi, W. M. M. (2015). Effect of poly ethylene glycol (PEG) on (fenoles compounds) production of Oleaeuropaea L. from callus in vitro. International Journal of Preclinical \& Pharmaceutical Research, 6(1), 16-19.

Anasori P., \& Asghari, G. (2008). Effects of light and differentiation on gingerol and zingiberene production in callus culture of Zingiber officinale Rosc. Research in Pharmaceutical Sciences, 3(1), 59-63.

Angelova, Z., Georgiev, S., \& Roos, W. (2006). Elicitation of plants. Biotechnology \& Biotechnology Equipment, 20(2), 72-83.

Ariani, R., Anggraito, Y. U., \& Rahayu, E. S. (2016). Respon pembentukan kalus koro benguk (Mucuna pruriens L.) pada berbagai konsentrasi 2,4-D dan BAP. Jurnal MIPA UNNES , 39(1), 20-28.

Ariany, S. P., Sahiri, N., \& Abdul, S. (2013). Pengaruh kuantitas cahaya terhadap pertumbuhan dan kadar antosianin daun dewa (Gynura pseudochina (L.) DC) secara in vitro. Agrotekbis, 1(5), 413420.

Azhar, N., Hussain, B., Ashraf, M. Y., \& Abbasi, K. Y. (2011). Water stress mediated changes in growth, physiology and secondary metabolites of desi ajwain (Trachyspermum ammiI L.). Pakistan Journal of Botany 43, 15-19.

Behbahani, M., Mehrnaz, S., \& Mohamad, J. H. (2011). Optimization of callus and cell suspension cultures of Barringtonia racemosa (Lecythidaceae family) for lycopene production. Science Agriculture, 68(1), 69-76.

Chattopadhyay, S., Sunita, F., Ashok, K. S., \& Virendra, S. (2002). Bioprocess considerations for production of 
secondary metabolites by plant cell suspension cultures. Biotechnology Bioprocess Engineering, 7(3), 138-149.

Gomes, I. B. S., Porto, M. L., Santos, M. C., Campagnaro, B. P., Pereira, T. M. C., Meyrelles, S. S., \& Vasquez, E. C. (2014). Renoprotective, anti-oxidative and antiapoptotic effects of oral low-dose quercetin in the $\mathrm{C} 57 \mathrm{BL} / 6 \mathrm{~J}$ model of diabetic nephropathy. Lipids in Health and Disease, 13(1), 184.doi: 10.1186/1476-511X-13-184.

Gupta, N., Bains, N. S., \& Thind, S. K. (2014). In vitro callus approach in selection for drought tolerance in bread wheat and its relation to yield performance under field drought conditions. Journal of Cell and Tissue Research, 14(2), 4315-4321.

Gupta, P., Sharma, S., \& Saxena, S. (2015). Biomass yield and steviol glycoside production in callus and suspension culture of Stevia rebaudiana treated with proline and polyethylene glycol. Application Biochemistry Biotechnology, 176(3), 863-874. doi: 10.1007/s12010015-1616-0.

Guo, R., Hao, W. P., Gong, D. Z., Zhong, X. L. \& Gu, F. X. (2013). Effects of water stress on germination and growth of wheat, photosynthetic efficiency and accumulation of metabolites. In M.C. Soriano (Eds.), Soil processes and current trends in quality assessment (pp. 367-380), London, UK: InTech Publisher.

Hao, G., Du, X., Zhao, F., Shi, R., \& Wang, J. (2009). Role of nitric oxide in UV-Binduced activation of PAL and stimulation of flavonoid biosynthesis in Ginkgo biloba callus. Plant Cell Tissue Organ Culture, 97(2), 175-185.

Hendaryono, D. P. S., \& Wijayani. (1994) Teknik kultur jaringan dan petunjuk: Perbanyakan tanaman secara vegetatif modern. Yogyakarta: Kanisius.

Humaira, A., \& Amien, S. (2019). Induksi kalus lima kultivar seledri (Apium graveolens L.) dengan sukrosa dan berbagai konsentrasi maltose. Agrin: Jurnal Penelitian Pertanian, 23(1), 1-11.

Jaleel, C. A., Manivannan, P., Wahid, A., Farooq, M., Somasundaram, R., \&
Panneerselvam, R. (2009). Drought stress in plants: A review on morphological characteristics and pigments composition. International Journal of Agriculture and Biology, 11(1), 100-105.

Janarthanam, B., Gopalakrishnan, M., \& Sekar, T. (2010). Secondary metabolite production in callus cultures of Stevia rebaudiana Bertoni. Bangladesh Journal of Scientific Industrial Research, 45(3), 243-248.

Kacem, N. S., Delporte, F., Muhovski, Y., Djekoun, A., \& Wattilon, B. (2017). In vitro screening of durum wheat against water-stress mediated through polyethylene glygol. Journal of Genetic Engineering and Biotechnology, 15(1), 239-247.

Kawazoe, S., Kobayashi, S., Mizukami, H., \& Ohashi, H. (1989). Cultivation and breeding of Uncaria rhynchophylla (Miq.) III. Effect of shading rate on growth, hook yield and alkaloid content. Japanese Journal Pharmacognosy 43, 104-108.

Kehie, M., Kumaria, S., \& Tandon, P. (2014). Osmotic stress induced capsaicin production in suspension cultures of Capsicum chinense Jacq.cv. Naga King Chili. Bioprocess Biosystem Engineering, 37(6), 1055-1063. doi:10.1007/s00449-013-1076-2.

Kintzios, S., Papanastasiou, I., Tourgelis, P., Papastellatos, C., Georgopoulos, V., \& Drossopoulos, J. (2002). The effects of light on callus growth and somatic embryogenesis from Lavandula vera and Teucrium chamaedrys: A preliminary study. Journal of Medicinal Plants 2, 223-227.

Kusbiantoro, D., \& Purwaningrum, Y. (2018) Pemanfaatan kadar metabolit sekunder pada tanaman kunyit dalam mendukung peningkatan pendapatan masyarakat. Jurnal Kultivasi, 17(1), 544-549.

Manuhara, Y. S. W. (2014). Kapita selekta kultur jaringan tumbuhan. Surabaya: Airlangga University Press.

Moghaddasian, B., Eradatmand, A. D., \& Alaghemand, A. (2012). Simultaneous determination of rutin and quercetin in 
different parts of Capparisspinosa. Bulletin of Environment, Pharmacology and Life Sciences, 2(2), 35-38.

Moitreyee, S., Shrivastava, K., \& Singh, S. S. (2013). Effect of culture media and growth hormones on callus induction in Aquilaria malaccensis Lam., a medicinally and commercially important tree species of North East India. Asian Journal of Biological Sciences, 6(2), 96105.

Nadir, M., Syahrir, R., \& Syamsia. (2018). In vitro selection of a drought tolerant callus of dwarf napier grass (Pennisetum purpureum Cv. Mott). IOP Conference Series: Earth and Environmental Science, 156, doi :10.1088/17551315/156/1/012024.

Purwaningsih, W., Febri, S., \& Kusdianti. (2016). Formation flavonoid secondary metabolites in callus culture of Chrysanthemum cinerariefolium as alternative provision medicine. AIP Conference Proceedings, 1708(1), 030005.

Ramani, S., \& Jayabaskaran, C. (2008). Enhanced catharanthine and vindoline production in suspension cultures of Catharanthus roseus by ultraviolet-B light. Journal of Molecular Signaling, 3(9). doi:10.1186/1750-2187-3-9.

Rao, S., \& Jabeen, F. T. Z. (2013). In vitro selection and characterization of polyethylene glycol (PEG) tolerant callus lines and regeneration of plantlets from the selected callus lines in sugarcane (Saccharum officinarum L.). Physiology and Molecular Biology of Plants, 19(2), 261-268. doi:10.1007/s12298-013-0162-x.

Rao, S., Usha, K., \& Arjun. (2015). Production of secondary metabolites from callus cultures of Centella asiatica (L.) urban. Annals of Phytomedicine, 4(1), 74-78.

Sauerwein, M., Wink, M., \& Shimomura, K. (1992). Influence of light and phytohormones on alkaloid production in transformed root cultures of Hyoscyamus albus. Journal Plant and Physiology, $140(2), 147-52$.

Selmar, D. (2008). Potential of salt and drought stress to increase pharmaceutical significant secondary compounds in plants. Landbauforschung - vTI Agriculture and Forestry Research, 58(1), 139-144.

Seenivasan, A., Gummadi, S. N., Panda, T., \& Theodore. T. (2015). Quantification of lovastatin produced by Monascus purpureus. The Open Biotechnology Journal, 9(7), 9-16.

Sharafzadeh, S. (2012) Growth and secondary metabolites of basil, mint and thyme as affected by light. International Journal of Pharma and Bio Sciences, 3(1), 43-46.

Shehab, G. G., Ahmed, O., \& El-Beltagi, H. S. (2010). Effects of various chemical agents for alleviation of drought stress in rice plants (Oryza sativa L.). Notulae Botanicae Horti Agrobotanici ClujNapoca, 38(1), 139-148. doi:10.15835/nbha3813627.

Shreedhara, C. S. (2013). Effect of elicitors on the production of hispidulin in the suspension culture of Millingtonia hortensis. International Journal of Multidisciplinary Research and Development Research, 1(12), 63-67.

Smith, A. J., Oertle, J., Warren, D., \& Prato, D. (2016). Quercetin: A promising flavonoid with a dynamic ability to treat various diseases, infections, and cancers. Journal of Cancer Therapy, 7(2), 83-95. doi: 10.4236/jct.2016.72010.

Sun, Q. L., Hua, S., Ye, J. H., Zheng, X. Q., \& Liang, Y. R. (2010). Flavonoids and volatiles in Chrysanthemum morifolium Ramat flower from Tongxiang County in China. African Journal of Biotechnology, 9(25), 3817-3821.

Rahayu, E. S., Guhardja, E., Ilyas, S., \& Sudarsono. (2005). Polietilena glikol (PEG) dalam media in vitro menyebabkan kondisi cekaman yang menghambat tunas kacang tanah (Arachis hypogaea L.). Berkala Penelitian Hayati, 11, 39-48.

Santoso, U. \& Nursandi, F. (2001). Kultur Jaringan Tanaman. Malang: Fakultas Pertanian Universitas Brawijaya.

Tabiyeh, D. T., Bernard, F., \& Shacker, H. (2006). Investigation of glutathione, salicylic acid and GA3effects on browning in Pistacia vera shoot tips 
culture. Acta Horticulturae, 726(726), 201-204.

doi: 10.17660/ActaHortic.2006.726.31.

Tavakkol, A., Angoshtari, R., \& Kalantari, S. (2011). Effects of light and different plant growth regulators on induction of callus growth in rapeseed (Brassicanapus L.) genotypes. Plants Omics Journal, 4(2), 60-67.

Vasconsuelo, A., \& Boland, R. (2007). Molecular aspects of the early stages of elicitation of secondary metabolites in plants. Plant Science, 172(5), 861-875.

Vanisree, M., Lee, C. Y., Lo, S. F., Nalawade, S. M., Lin, C. Y., \& Tsay, H. S. (2004). Studies on the production of some important secondary metabolites from medicinal plants by plant tissue cultures. Botanical Bulletin of Academia Sinica, 45,1-22.

Xie, Y. Y., Yuan, D., Yang, J. Y., Wang, L. H., \& Wu, C. F. (2009). Cytotoxic activity of flavonoids from the flowers of Chrysanthemum morifolium on human colon cancer colon 205 cells. Journal of Asian Natural Products Research, 11(9), 771-778.

Yazaki, K., Matsuoka, H., Ujihara, T., \& Sato, F. (1999). Shikonin biosynthesis in Lithospermum erythrorhizon: Lightinduced negative regulation of secondary metabolism. Plant Biotechnology, 16(5), 335-342. 